\title{
Economic Valuation of Mangrove Ecosystem at Gerung District, West Lombok Regency
}

\author{
Mufti Petala Patria*, Siti Dian Rosadi, Nisyawati \\ Department of Biology, Faculty of Mathematics and Natural Sciences, Universitas Indonesia, Depok, Indonesia
}

ARTICLE INFO

\section{Article history:}

Received October 20, 2020

Received in revised form March 1, 2021

Accepted March 10, 2021

KEYWORDS:

Economic valuation,

Gerung,

Mangrove

\begin{abstract}
Research regarding economic valuation of mangrove in Gerung District, West Lombok Regency has been conducted. The purposes of this research were to calculate and analyze economic value from mangrove ecosystem at Gerung District. Research methods used observation and interviews. Direct Economic Value (DEV) were obtained from direct use of mangrove with a value IDR. $\mathbf{2 2 7 , 0 4 0 , 0 0 0 / y e a r . ~ I n d i r e c t ~ E c o n o m i c ~ V a l u e ~ ( I E V ) w e r e ~ c a l c u l a t e d ~ f r o m ~ m a n g r o v e ~}$ ecosystem services with a value IDR. 1,405,041,200/year, Existence Value (EV) was obtained by Contingent Valuation Method (CVM) with a value IDR. 1,520,000/ year. Option Value $(\mathrm{OV})$ were calculated from biodiversity value with a value were IDR. 1,200,000/year. Total Economic Value (TEV) of mangrove in Gerung District were IDR. 1,634,801,200/year.
\end{abstract}

\section{Introduction}

Mangrove ecosystems in Indonesia continue to suffer damage (Kuswata et al. 1977). Of the 7.7 million hectares of existing mangrove area, 3.25 million ha were damaged (Kementerian Kehutanan Republik Indonesia 2012). Mangrove damage in Indonesia is one of them on Lombok Island (Budhiman et al. 2001; Bonita and Nizar 2014; Junaidi 2014; Subhan 2014). As many as $50.3 \%$ of mangrove ecosystems in Lombok Island were damaged (Badan Pengendalian Daerah Aliran Sungai 2007). The damage was caused by land conversion (Subhan et al. 2014), tourism (Wong 1998), illegal logging and exploitation of building materials and fuelwood (Bonita and Nizar 2014; Junaidi 2014). Gerung is one of the districts in Lombok that has a mangrove ecosystem. Mangrove ecosystem in Gerung District is spread in Taman Ayu Village and Kebun Ayu. Mangrove Taman Ayu village is owned jointly by the community while in Kebun Ayu Village is privately owned.

People who live around the mangrove area of Taman Ayu Village are generally still traditional. This can be seen from the forms of buildings and life habits of people who still use natural products from mangroves such as building materials, animal feed, and firewood.

\footnotetext{
* Corresponding Author

E-mail Address: mpatria@ui.ac.id
}

People living around the Kebun Ayu Village mangroves has a more modern lifestyle, so it is rarely used natural products from mangroves. This is related to the community profession which is generally an entrepreneur. They get more variety of life necessities from the market than using it directly from nature. In addition, because the mangrove area is owned privately, the community is also limited in utilizing mangroves. The community can only utilize coconut fruits, fisheries and tourism products.

Based on observations it can be seen that Gerung District has a mangrove area of 31 ha which is spread as much as 16 ha in Taman Ayu Village and 15 ha in Kebun Ayu Village. The biggest problem faced by the mangrove ecosystem in Taman Ayu Village is related to the high level of exploitation. The biggest exploitation is carried out on sand and wood. This can be seen from the many activities of timber harvesting and utilization and the number of sand mining activities in the mangrove area. As for the Kebun Ayu Village, the main problem faced is mangrove conversion into fishing area and plantation locations. Of the 50 ha of existing mangrove areas, 36 ha have been converted. Various mangrove destruction activities are part of the direct use of mangroves (Johari 2007; Arifitria et al. 2014). The community does not understand that mangroves have a lot of economic value that is not only obtained from direct use (Setiyowati 2016). This 
economic value can be obtained from indirect benefits, option benefits and the benefits of the existence of mangroves (Suzana et al. 2011; Zen and Ulfa 2013; Wahyuni et al. 2014; Setiyowati 2016; Widiastuti et al. 2016). The various benefits of mangroves do not provide direct economic benefits, but the economic value of the benefits generated can be measured and known through economic valuation research.

\section{Materials and Methods}

The study was conducted from February until August 2018. The data were collected in Gerung District, West Lombok Regency, Indonesia (Figure 1.). Collecting data was conducted through observasi and interviews (Johari 2007; Zen and Ulfah 2013; Wahyuni et al. 2014). The informants were 60 people or $10 \%$ of the total population in the village. These percentage values are commonly used in various studies representing the total population of the sample. Data collected includes mangrove values from direct use, indirect use, options values and existence values.

Direct Use value (DUV) is the economic value obtained from the direct use of natural resources and the environment (Barbier et al. 1994). Economic value data from the direct use of mangroves are evaluated from the utilization of forest products (Barbier et al. 1994; Johari 2007) and fishery products (Barbier et al. 1994).

Indirect Use Value (IUV) is the economic value obtained from indirect use of natural resources and the environment (Barbier et al. 1994; Suzana et al. 2011; Widiastuti 2016). The economic value of indirect benefits is evaluated from abrasion containment costs (Suzana et al. 2011; Arifitria et al. 2014; Widiastuti et al. 2016), feed providers (Noor and Helminuddin 2009), nursery ground, spawning ground, and feeding ground (Hiariey 2009; Arifitria et al. 2014; Widiastuti et al. 2016).

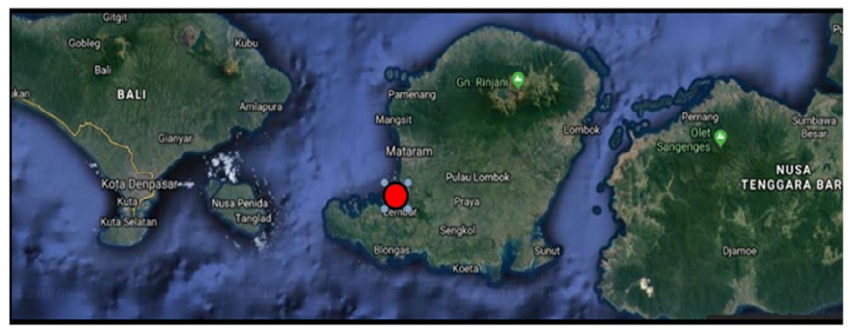

Figure 1. Map of location of data retrieval
Option Value (OV) represents the potential economic value derived from the use of resources in the future (Barbier et al. 1994). This value evaluated from the value of biodiversity (biodiversity) (Hiariey 2009; Suzana et al. 2011; Arifitria et al. 2014; Wahyuni et al. 2014; Widiastuti et al. 2016). The benefits of Existence Value (EV) are evaluated based on the desire to pay (WTP; Willingness to Pay) from the community to maintain the existence of mangroves (Noor and Helminuddin 2009).

\section{Results}

All mangrove destruction activities carried out by the Gerung community are part of direct utilization whose economic value can be evaluated. However, these uses tend to be destructive. The community does not consider that the economic value of other benefits can also provide large economic value. The following is the overall economic value of mangroves in Gerung District that has been evaluated:

\subsection{Direct Use Value}

The economic value of the direct use value of the Taman Ayu Village mangrove is IDR. 29,474,000 and for the Taman Ayu Village mangrove is IDR. 227,040,000. When combined with the total economic value resulting from the direct benefits of mangroves in Gerung district reaching IDR. 256,514,000.

\subsection{Indirect Use Value}

The indirect value of mangroves in Gerung District which were evaluated include abrasion, waves and tsunamis (Table 1). Economic value is quantified by the replacement cost method by estimating the economic value of making break water.

The cost of making a dike with a size of $50 \times 1.5$ x $2.5 \mathrm{~m}(\mathrm{p} \mathrm{x} 1 \times \mathrm{t})$ with a 5 year durability of IDR. $291,994,000$ or IDR. $5,839,880 /$ meter. The length of the

Table 1. Indirect use value

Estimated resources Amount (IDR./year)

Break water $2,557,867,440$

Nursery ground, spawning ground $8,310,000$ dan feeding ground

Total $2,566,177,440$ 
coastline in Gerung District is 2,190 meters, so that the economic value is IDR. $12,789,337,200 /$ meter or IDR. $2,557,867,440 /$ year.

Other indirect benefits that are evaluated are as nursery, spawning and feeding ground. The value is quantified from the catch of fishery products obtained by the community from the mangrove area. The calculation results show that the economic value obtained reaches IDR. 8,310,000/year.

\subsection{Option Value}

The values are generally quantified using the benefit transfer method, which is by calculating the amount of biodiversity in the mangrove ecosystem. Mangrove forests in Indonesia have a biodiversity value of US $\$ 15 /$ ha. Based on this, the economic option value of the mangove Gerung District in 2018, reaching US $\$ 465 /$ ha or IDR. $6,510,000 /$ ha.

\subsection{Existence Value}

This value measures how much the economic value provided by the community reflects the level of public concern for natural resources and the environment. Value quantification is done by directly measuring individual preferences through the Contingent Valuation Method (CVM). The method is done by asking how Willingness To Pay (WTP) from the community in maintaining the existence of mangroves. Economic value is obtained by adding the average value (IDR.) given by the informant to the presence of mangroves per ha per year. Through the CVM approach to 60 informants, it can be seen that the value of the existence benefits of the Gerung District mangrove ecosystem reaches IDR. 400,000/ ha/year or IDR. $12,400,000 /$ year.

\subsection{Total Economic Value}

Total Economic Value is the overall economic value of direct benefits, indirect benefits, choice benefits, and the benefits of existence. The mangrove TEV in Gerung District in 2018 reached IDR. 1,634,801,200/ year (Table 2).

Table 2. Total economic value

\begin{tabular}{lr}
\hline Benefit & Amount (IDR./year) \\
\hline Direct use value (DUV) & $256,514,000$ \\
Indirect use value (IUV) & $2,566,177,440$ \\
Option value (OV) & $6,510,000$ \\
Existence value (EV) & $12,400,000$ \\
\hline Total & $2,841,601,440$ \\
\hline
\end{tabular}

\section{Discussion}

\subsection{Direct Use Value}

When compared, the economic value generated from the mangroves of Taman Ayu Village is high more than the mangroves of Kebun Ayu Village (Table 3). This is caused by the smaller size of the Kebun Ayu mangrove area, but the difference is only 1 ha. Based on the results of vegetation analysis, the density of mangroves in Kebun Ayu Village is indeed no more dense than Taman Ayu Village, so there are not many resources available. This is one reason for the low economic value of direct mangrove benefits in Taman Ayu Village.

Based on Table 3. the highest mangrove economic value of Taman Ayu Village was obtained from the use of sand which was IDR. 189,000,000/year. Based on observations, it can be seen that the high utilization of sand in the mangrove area of Taman Ayu Village is caused by the high availability of sand resources.

Another high utilization of mangroves in Taman Ayu Village is fuelwood. The economic value reaches IDR. 9,860,000/year. The high use of fuelwood is caused by people who are still traditionally using stoves.

The lowest economic value is obtained from coconut leaves. This is related to the frequency of utilization which is very rare. Besides that, unlike food or building needs, young coconut leaves are only used at certain times.

As for Kebun Ayu Village, the highest economic value obtained from tourism is IDR. 9,900,000/year. This value is obtained from the multiplication of the entrance ticket price of IDR. 10,000/ticket multiplied by the number of visits each year which reached 990 times. The high economic value generated from tourism shows the high interest of the community to seek entertainment needs.

Other high economic values are generated from coconuts. The economic value reaches IDR. 9,720,000/ year. The high utilization of coconut trees which are intentionally planted by their owners because they are considered to have high economic value.

The lowest economic value is obtained from the use of fuelwood. This is due to the limited community to utilize wood from privately owned mangrove land. Based on observations it can be seen that modern lifestyles cause people to no longer use fuelwood when cooking. In addition, the availability of low 
Table 3. Direct use value

\begin{tabular}{lcclrrr}
\hline Resources & \multicolumn{2}{c}{ Taman Ayu } & & Resources & \multicolumn{2}{c}{ Kebun Ayu } \\
\cline { 2 - 3 } \cline { 5 - 6 } & Amount (IDR./year) & Persentage (\%) & & Amount (IDR./year) & Persentage (\%) \\
\hline Shrimps & $1,530,000$ & 0.67 & & Snail & 460,000 & 1.56 \\
Shells & $1,664,000$ & 0.73 & & Shells & $4,000,000$ & 13.57 \\
Fuelwood & $9,860,000$ & 4.34 & & Tourism & $9,900,000$ & 33.59 \\
Fish & 216,000 & 0.10 & & Bait (rock moss) & $4,422,000$ & 15.0 \\
Crabs & 60,000 & 0.03 & & Coconut & $9,720,000$ & 32.98 \\
Sand & $189,000,000$ & 83.25 & & Shrimp bait & 360,000 & 1.22 \\
Coconut & $6,900,000$ & 3.04 & & Fuelwood & 60,000 & 0.20 \\
Cocnut leaf & 45,000 & 0.02 & & Building material & 420,000 & 1.42 \\
Grass & $12,125,000$ & 5.34 & & Fish & 132,000 & 0.45 \\
Bamboo & $1,680,000$ & 0.74 & & & \\
Fruits & $3,960,000$ & 1.74 & & Total & $29,474,000$ & 100 \\
\hline Total & $227,040,000$ & 100 &
\end{tabular}

mangrove trees also results in the low acquisition of mangroves for fuelwood. This can be seen from the low density of remaining mangrove trees.

\subsection{Indirect Use Value}

The economic value generated from the indirect benefits of mangroves in Gerung District reaches IDR. $2,566,177,440 /$ year (Table 2). The values obtained indicate that mangroves play a large role in producing economic value even though these benefits cannot be felt directly (Rahmah et al. 2014). If mangroves suffer damage, the economic losses that the community will feel can be equivalent to the economic value that has been evaluated (Fauzi 2004).

\subsection{Option Value}

Option value of the mangove Gerung District in 2018 , reaching US $\$ 465 /$ ha or IDR. $6,510,000 /$ ha. This value is the result of the multiplication of biodiversity values with an area of mangrove forest that is 31 ha. The value of biodiversity can explain the importance of the role of diversity of organisms that make up an ecosystem. Plants, animals and microorganisms in the ecosystem can certainly provide great benefits (Barbier et al. 1994).

\subsection{Existence Value}

According to Wahyuni et al. (2014) and Arifitria et al. (2014), the high or low of existence value given by the community can also indicate the high and low levels of community concern for the preservation of mangroves (Arifitria et al. 2014). Existence Value obtained can explain the importance of the existence of mangroves for the future. The greater the value is obtained, the greater the possibility of benefits that can be obtained in the future. If mangroves are damaged and lost, there are not many economic values that can be calculated.

\subsection{Total Economic Value}

Based on Table 3. When compared between all existing values, the largest economic value is more obtained from the Indirect Use Value (IUV). Purida and Patria (2020) found the same result at the mangrove ecosystem in Cimalaya Wetan, West Java. This indicates that ecosystem services produced by mangroves play an important role in providing economic benefits. The other highest economic value is obtained from the Direct Use Value (DUV). This indicates that the level of community exploitation of mangroves is still very high. Whereas the low value of Option Value (OV) and Existence Value (EV) is caused by the lack of public awareness on the importance of mangrove existence and potential in the future in providing economic benefits.

\section{Conclusion}

Direct Use Value (DUV) for forest mangrove benefits were IDR. 256,514,000/year. Indirect Use Value (IUV) were IDR. 2,566,177,440/year. Existence Value (EV) were IDR. 12,400,000/year. Option Value (OV) reach 6,510,000/year. Total Economic Value(TEV) of Gerung district mangrove was IDR. 2,841,601,440/ year. This value indicates that mangroves have economic value that is not only obtained from direct value, but also indirect value, option value and the existence value. 


\section{Acknowledgements}

Thank you to village Head and all staff involved. Do not forget to all the interviewees who have been active in the data collection activities. Thank for the founds from hibah PITTA (Publikasi Terindeks Internasional untuk Tugas Akhir) UI 2018.

\section{References}

Arifitria RI et al. 2014. Nilai ekonomi total hutan mangrove Desa Margasari, Kecamatan Labuan Maringgai, Kabupten Lampung Timur. J Sylva Lesatri 2:19-28.

[BPDAS] Badan Pengendalian Daerah Aliran Sungai. 2007. Kondisi dan status mangrove di wilayah kerja BPDAS Dodokan Moyosari. UPT Direktorat Jenderal Rehabilitasi dan Perhutanan Sosial, Departemen Kehutanan Propinsi Nusa Tenggara Barat, Lombok.

Barbier EB. 1994. Valuing Environmental Functions: Tropical Wetlands. Wisconsin: University of Wisconsin Press.

Bonita MK, Nizar WY. 2014. Analisis kerusakan hutan mangrove di wilayah pesisir Sekotong, Kabupaten Lombok Barat. J Media Bina Ilmiah 8:63-71.

Budhiman SR et al. 2001. Kerusakan hutan mangrove di Pulau Lombok menggunakan data landsat-TM dan sistem informasi geografis (SIG). Warta LAPAN 3:200-210.

Fauzi A. 2004. Ekonomi Sumberdaya Alam dan Lingkungan: Teori dan Aplikasi. Jakarta: Gramedia Pustaka Utama.

Hiariey LS. 2009. Identifikasi nilai ekonomi ekosistem hutan mangrove di Desa Tawiri, Ambon. Jurnal Organisasi dan Manajemen 5:23-34.

Johari HI. 2007. Analisis nilai ekonomi total mangrove di Kabupaten Lombok Timur Bagian Selatan, Nusa Tenggara. Media Bina Ilmiah 3:1-6.

Junaidi. 2014. Identifikasi komposisi vegetai mangrove di kawasn wisata alam Bangko-Bangko, Kabupaten Lombok Barat. J Penelitian Universitas Mataram 8:6180.

Kementerian Kehutanan. 2012. Statistik Kehutanan Indonesia 2011. Direktorat Jenderal Planologi, Kehutanan, Jakarta.
Kuswata Ket al. 1997. Kondisi hutan payau Teluk Jakarta dan pulau-pulau sekitarnya. JOseonologi Indonesia 7:1-23.

Noor P, Helminuddin. 2009. Valuasi Ekonomi Pemanfaatan Hutan Mangrove di Kelurahan Teritip, Balikpapan. J Kehutanan Tropika 2:69-80.

Purida N, Patria MP. 2020. Economic valuation of mangrove ecosystem in Cilamaya Wetan, Karawang, West Java. IOP Conf Ser: Earth Environ Sci 404:012016. DOI:10.1088/1755-1315/404/1/012016

Rahmah F et al. 2014. Potensi karbon tersimpan pada lahan mangrove dan tambak di kawasan pesisir Kota Banda Aceh. I Manajemen Sumber Daya Lahan 4:527-534.

Ruitenbeek HJ. 1991. Mangrove management: An economic analysis of management option with a focus on Bituni Bay, Irian Jaya. Environmental Management Development in Indonesia Project, Jakarta.

Setiyowati et al. 2016. Economic valuation of mangrove resources in the Mangunharjo Village Tugu Sub District, Semarang City. Indonesian Journal of Fisheries Science and Technology 12:67-74.

Subhan M et al. 2014. Analisis tingkat kerusakan dan strategi pengelolaan mangrove di kawasan Suaka Perikanan Gili Ranggo Teluk Sewire Kabupaten Lombok Timur Nusa Tenggara Barat. J Ecotrophic 8:86-92.

Suzana BO et al. 2011. Valuasi ekonomi sumber daya hutan mangrove Desa Palaes, Kecamatan Likupang Barat, Kabupaten Minahasa Utara.J Akademik Sains Economic $7: 29-38$

Wahyuni Y et al. 2014. Valuasi total ekonomi hutan mangrove di kawasan Delta Mahakam, Kabupaten Kutai Kartanegara, Kalimantan Timur. J Penelitian Kehutanan Wallacea 3:1-12.

Widiastuti MMD et al. 2016. Valuasi ekonomi ekosistem mangrove di wilayah pesisir Kabupaten Merauke. J Sosial Ekonomi 11:147-159.

Wong PP. 1998. Coastal tourism development in Southeast Asia: Relevance and lesson for coastal zone management. Ocean and Coastal Manajement 38:89109.

Zen LW, Ulfah F. 2013. Valuasi ekonomi hutan mangrove di pulau Dompak, Kota Tanjung Pinang, Provinsi Kepulauan Riau. J Dinamika Maritim 4:45-52. 